\author{
WIESŁAW BORYŚ \\ Polska Akademia Nauk \\ Instytut Slawistyki
}

\title{
Najstarsza słowiańska leksyka intelektualna
}

Słow a klucze: historia leksyki słowiańskiej, leksyka prasłowiańska, etymologia słowiańska

W artykule omawiam słowiańskie słownictwo z zakresu wyższych czynności mózgu, czyli przejawów intelektu, przy czym chcę się ograniczyć do najstarszej części tego słownictwa, mianowicie tej, którą mamy podstawy zaliczać do leksyki istniejącej już w epoce prasłowiańskiej wspólnoty językowej, przed jej rozpadem na dialekty kontynuowane później przez znane historycznie odrębne języki słowiańskie. Prasłowiańska warstwa leksyki słowiańskiej znana jest dotychczas częściowo, trwają prace nad jej rekonstrukcją, wydawane są dwa słowniki temu poświęcone, krakowski Słownik prasłowiański i moskiewski Etimologičeskij slovar' slavjanskich jazykov. Poza tym wydawane były i są różnorodne studia i artykuły zajmujące się fragmentami tej leksyki bądź poszczególnymi wyrazami lub też rodzinami wyrazów; są to najczęściej studia etymologiczne. Trzeba przy tym stwierdzić, że lepiej jest zbadana leksyka odnosząca się do słowiańskiej kultury materialnej, znacznie gorzej leksyka z zakresu kultury duchowej dawnych Słowian. Wśród tych słabiej zbadanych działów słownictwa prasłowiańskiego jest również leksyka odnosząca się do przejawów aktywności intelektualnej, chociaż oczywiście zajmowano się etymologią poszczególnych leksemów; nie ma wszakże całościowego ujęcia tego wycinka starej słowiańskiej leksy- 
ki; jedyną znaną mi próbę ujęcia całościowego słowiańskiej ludowej „nomenklatury przejawów intelektu" przedstawił K. Moszyński w Kulturze ludowej Słowian (Moszyński 1967: 93-97).

W artykule rozpatruję tylko leksemy, które zasadnie można rekonstruować jako prasłowiańskie, wyjątkowo też wymieniam leksemy, które bywają uznawane za prasłowiańskie, ale których przynależność do prasłowiańskiej warstwy leksyki uważam za dyskusyjną lub bardzo wątpliwą, chodzi tu nie tyle o wyrazy o ograniczonym zasięgu na obszarze słowiańskim (bo rozpowszechnienie wyrazu nie może być głównym kryterium zaliczania go do warstwy prasłowiańskiej), co raczej o wyrazy, których struktura i ewentualnie semantyka świadczą, że mogły powstać już po rozpadzie wspólnoty prasłowiańskiej. W odniesieniu do pewnych wyrazów, których budowa nie wykazuje wielkiej archaiczności i które nie mają nawiązań pozasłowiańskich, nieraz można mieć wątpliwości, czy powstały w epoce prasłowiańskiej, czy może już po rozpadzie prajęzyka, we wczesnej fazie epoki poprasłowiańskiej na gruncie jednego języka czy nawet kilku języków słowiańskich. Przyczyną jest bliskość prasłowiańskiego systemu słowotwórczego i systemów słowotwórczych poszczególnych języków słowiańskich, zwłaszcza we wczesnych okresach ich samodzielnego rozwoju.

Poniżej została rozpatrzona geneza poszczególnych leksemów prasłowiańskich i ich pierwotna semantyka, przedstawione zostały różne wersje etymologicznych objaśnień poszczególnych wyrazów. Analizowany materiał został podzielony ze względu na prawdopodobne znaczenie w epoce prasłowiańskiej na 9 grup semantycznych. Interesuje mnie także kształtowanie się rozpatrywanego działu leksyki prasłowiańskiej.

1. 'rozum, umysł, intelekt': *umb 'rozum, umysł, intelekt': stpol. XV w. um 'rozum, sprawność umysłu, zdolność myślenia', 'zamiar, postanowienie', pol. dial. um 'myśl', czes. um 'rozum', 'umiejętność', słowac. um 'rozum, umysł', ros. um, umá 'rozum, umysł, intelekt', ukr. um, umá 'rozum', brus. um 'ts.', scs. umъ 'rozum, umysł', 'myśl', bułg. um 'rozum, umysł; pamięć', maced. um 'umysł, rozum; pamięć', chorw. i serb. ûm, úma 'umysł, rozum; zmysł; pamięć', słoweń. úm 'rozum, umysł; rozsądek'. Wyraz pochodzi z prapostaci *au-mo-, pokrewnej lit. аитио̃ 'rozum, intelekt' (z prapostaci *au-men-), dial. wsch. aumenis 'pamięć'. Psł. *umъ i lit. aumuõ to niezależnie utworzone za pomocą odrębnych sufiksów derywaty od pie. pierwiastka 
werbalnego *au- 'odbierać zmysłami, czuć; rozumieć' (por. np. Miklosich 372, Vasmer III, 183, Bezlaj IV, 263, Rejzek 2001: 690, Pokorny 78, Derksen 2008: 508-509, Fraenkel I, 26, Smoczyński 2007: 34). Etymologiczne znaczenie psł. 'umъ to przypuszczalnie 'czucie, rozumienie'.

*orzumb 'rozumienie, pojmowanie', skonkretyzowane w 'rozum, umysł': pol. od XIV w. rozum 'władza poznawcza umysłu ludzkiego, umysł, inteligencja', 'umiejętność radzenia sobie w życiu, mądrość, roztropność, rozsądek', dawniej też 'fortel, pomysł, podstęp', dłuż. rozym (dawne rozum) 'rozum, umysł, rozsądek; sens, znaczenie', głuż. rozom / rozym / rozum 'myślenie, rozumienie, poznanie; rozum, umysł, rozsądek', czes. rozum 'rozum', 'zdanie, sąd, pogląd, pomysł', słowac. rozum 'rozum, umysł', pot. rozumy pl. 'pomysły', strus. rozums 'sens, znaczenie; znak, wskazanie', ros. dial. rózum 'rozum, umysł' (w języku literackim razum 'rozum, intelekt' z cs. razumъ), ukr. rózum 'rozum, umysł, intelekt', brus. rózum 'umysł, rozum; rozsądek', scs. razumъ 'rozum, intelekt', 'mądrość, rozumność', 'pojmowanie, rozumienie', 'myśl, myślenie', bułg. rázum 'rozum', maced. razum 'ts.', chorw. i serb. räzūm 'rozum, rozsądek, umysł; zmysł', słoweń. razúm 'rozum, rozsądek, umysł'. Psł. *orzumъ objaśniane jest dwojako. Część badaczy (np. Vasmer III, 435, Schuster-Šewc 1244, Bezlaj III, 160, BER VI, 161-162, ESBM XI, 174-175) uznaje ten wyraz za derywat z prefiksem *orz- od psł. *um 'rozum, umysł, intelekt', przy czym prefiksem miałaby być wyrażona odróżniająca zdolność myślenia („,rozlišovací schopnost myšlení”, Rejzek 2001: 548). Jednakże semantyka wyrazu, a także fakt, że prefiks *orz- był produktywny przede wszystkim jako prefiks czasownikowy, przemawia raczej za dewerbalną genezą psł. *orzumъ. Jest to zatem rzeczownik dewerbalny od psł. prefigowanego czasownika *orz-uměti 'pojąć, poznać, zrozumieć', pierwotnie nazwa czynności 'rozumienie, pojmowanie', wtórnie skonkretyzowana w 'rozum, umysł' (np. Skok III, 544, Boryś 2005: 523). W ESSJa 35, 134-138 dopuszczono obie interpretacje wyrazu.

2. 'pamięć': *pamętb 'wspomnienie, przypomnienie czegoś, pamięć': pol. od XIV w. pamięć 'zdolność umysłu do przyswajania, utrwalania i przypominania doznanych wrażeń, przeżyć, wiadomości', 'pamiętanie, wspominanie', dawniej 'przytomność, świadomość', czes. pamět' 'pamięć', paměti pl. 'pamiętnik, wspomnienia', słowac. pamät' 'pamięć', strus. pamjatb 'ts.', ros. pámjatb 'ts.', ukr. pám’ jatb 'ts.', brus. pámjacb 'ts.', scs. pamętb 'ts.', bułg. 
pámet 'ts.', ludowe 'rozum', maced. pamet 'pamięć; umysł, rozum; myśl; rada, pouczenie', chorw. i serb. pämēt 'rozum; umysł; pamięć', słoweń. pámet 'rozum, rozsądek'. Psł. *pamęt to archaiczne złożenie, z pierwszym członem *pa- wnoszącym znaczenie 'później, późniejszy', człon drugi *mętb jest identyczny z lit. mintìs 'myśl', łac. mēns, mentis 'myśl, rozum', stind. matí- 'myśl, mniemanie' (por. też lit. at-mintìs i iš-mintìs 'pamięć', goc. ga-munds 'ts.'), kontynuuje on pie. *men-ti-s, gen. *mn-tei-s 'myśl', które od pie. pierwiastka werbalnego *men- / *mn- 'myśleć' (por. np. Vasmer III, 195, Bezlaj III, 6-7, Boryś 1975: 23, Boryś 2005: 409, ESJS 10, 624). Pierwotne znaczenie psł. *pamętb to 'późniejsza myśl, przypomnienie, wspomnienie'. Ze względu na archaiczną strukturę wyrazu nie przekonuje uznawanie *pamętb za derywat od czasownika *po-mbněti 'wspominać, przypominać sobie' (np. Meillet 1905: 276, 278, Machek 1968: 430).

3. 'czynności umysłu, myślenie, rozmyślanie, myśl': *myslb 'myślenie, myśl': pol. od XIV w. myśl 'czynność umysłu, myślenie, rozum, umysł, świadomość', 'wynik rozmyślań, skutek myślenia', dłuż., głuż. mysl 'myśl; umysł, usposobienie; zdanie, opinia; zamiar', czes. mysl 'myśl; odwaga, otucha', słowac. mysel', -sle : -sli 'myślenie, myśli, umysł; myśl; pamięć', strus. myslb 'myśl, myślenie, rozum, świadomość; idea; sąd o czymś, przekonanie, mniemanie; zamiar', ros. myslb 'myśl', ukr. myslb 'ts.', brus. myslb 'myśl, myślenie; myśli, poglądy', scs. myslb 'myśl; sąd, mniemanie; zamiar, zamysł', bułg. mísъl 'myśl; zamysł', maced. misla 'myślenie, myśl; troska; zamiar; chęć, zamiar; pogląd', chorw. i serb. mîsao, mîsli 'myśl, pomysł, zdanie; chęć, zamiar', słoweń. mísel 'myśl; pomysł'. Geneza psł. *myslb nie jest dotychczas ostatecznie wyjaśniona, istnieje wiele wersji etymologii tego wyrazu; bodaj najbardziej szczegółową krytyczną ich analizę przedstawił V. N. Toporov (Топоров 1963), а później O. N. Trubačev (ESSJa 21, 47-50), por. też ESJS 9, 508-509. Według najczęściej przyjmowanej etymologii psł. *myslb kontynuuje prapostać *myd-slb z wcześniejszego (pie.?) *mū $d^{h}$-slü-, nie mającą odpowiedników w innych językach indoeuropejskich. Uważa się, że rzeczownik ten jest derywatem od pie. pierwiastka werbalnego *mēu $u d^{h}-/ *_{m}$ mu $d^{h}-$ / *mū $d^{h}$ - 'uważać na coś, myśleć o czymś', od którego mają pochodzić także lit. maũsti, maudžiù 'pragnąć czegoś, tęsknić', goc. ga-maudjan 'przypominać', gr. mỹthos 'słowo, mowa; powiedzenie, przysłowie; pogłoska, wieść; opowiadanie, legenda, mit, bajka'. Przy przyjęciu takiej etymologii psł. *myslb jako 
derywat z sufiksem $*_{-s l \breve{l}->} *_{s l b}$, tworzącym nomina actionis (Sławski 1974: 106-107), miałby pierwotne znaczenie 'uważanie na coś, myślenie o czymś'. Jednakże taka etymologia bywa kwestionowana z powodu dyskusyjnego zestawienia z faktami bałtyckimi: lit. maũsti, maudžiù przez bałtystów (Fraenkel I, 420, Smoczyński 2007: 378-379) nie jest łączone z psł. *myslb, lecz z inną słowiańską rodziną wyrazową: psł. *mъdèti ‘być słabym, zmęczonym' (por. np. ros. dial. modétb 'męczyć się, nużyć się; gnuśnie pracować, ślęczeć nad czymś; zwlekać, odwlekać; niknąć, chudnąć; tlić się; gnić', cs. izmъděti 'osłabnąć'), *mъdъlъ 'słaby, bezsilny, wątły' (np. pol. mdty 'pobudzający do wymiotów, nudności, mdlący, bez smaku; słabo świecący, mglisty, zamglony, blady, nikły; pozbawiony wyrazu, ekspresji, mało wyrazisty', stpol. 'słaby, wątły, bezsilny, wycieńczony'), *muditi 'tracić czas, zwlekać, ociągać się' (np. stpol. mudzić 'opóźniać /się/, zwlekać, tracić czas', pol. dial. 'mitrężyć, marudzić; zajmować czas; tracić czas'). Zestawienie psł. *myslb z lit. maũsti, maudžiù oraz z psł. *mъděti, *mъdъlъ, *muditi przyjmuje np. A. Bańkowski, który w związku z tym dopuszcza pierwotne znaczenie psł. *myslb jako „raczej pejoratywne: 'co czyni słabszym, powolniejszym, dolega, przeszkadza, opóźnia w działaniu"' (Bańkowski 2000: II, 233). Autor ten w jakimś stopniu nawiązywał do A. Brücknera, wg którego myśl ,przyrostkiem -sl- lub -tl- od mud-(p. mudzić) i mad-(jak łyko : łaczyć, być : będę i inne), por. goc. maudjan 'przypominać'; myśl nazwana więc od mudzenia, 'zwlekania', aby nie być po szkodzie dopiero mądrym” (Brückner 350). Niektórzy badacze zestawiali psł. *myslb tylko z gr. mỹthos (np. Machek 1968: 385, Derksen 2008: 337). Od dawna podejmowano też próby powiązania psł. *myslb pie. pierwiastkiem *men- / *mn- 'myśleć' (np. Miklosich 1886: 208 pisał „Man vergleicht got. ga-maud-jan: in diesem falle wäre myslb zu deuten aus myd-tlb. Andere stellen ein man-sli auf'), z zaliczanym do tego pierwiastka goc. gamaudjan 'przypominać’ łączył psł. *myslb także A. Vaillant (1974: 558). Oryginalną etymologię, głęboko uzasadnioną (zwłaszcza semantycznie) zaproponował V. N. Toporov: psł. * myslb wyprowadził z pierwotnej postaci *mon-slǐ-, mającej być derywatem z wokalizmem -o- od pie. *men-, a słowiański rzeczownik zestawił z lit. mąslus 'myślący, wnikliwy, pojętny' (Топоров 1963), jednakże niepewny, mimo starań autora, pozostaje rozwój *on $>*$ *y.

*sqdb 'zdanie, opinia, pogląd' (np. pol. sąd 'zdanie, opinia, pogląd', czes. soud 'ts.'). Psł. *sodb to prastare złożenie, kontynuujące pie. $*^{*} s o m-d^{h} o-$ 'zestawienie, złożenie razem, złączenie', które było złożone z pie. *som- 'razem, 
z' i z derywatu od pie. * $d^{h} \bar{e}$ - 'kłaść, stawiać' (por. np. stpol. i dial. dziać 'położyć, umieścić, podziać', stczes. dieti 'umieścić, położyć, schować', chorw. djèti 'wsadzić gdzieś, włożyć, położyć'). Psł. *sqdz ma bliskie odpowiedniki w stind. samdhi- 'złączenie; obcowanie; pokój; umowa' i w lit. samdà 'wynajem’ (por. np. Trautmann 48, Vasmer III, 794, Bezlaj III, 283-284, Rejzek 591, Boryś 2005: 539, Derksen 2008: 462-463). Omawiany wyraz miał zapewne pierwotne znaczenie 'zestawianie, składanie, złożenie, złączenie', z którego musiało się rozwinąć znaczenie 'składanie myśli, wyciąganie wniosków, ustalanie zdania, opinii, poglądu na temat kogoś lub czegoś', a z tego z kolei wyspecjalizowane znaczenie 'rozstrzyganie czegoś (np. sporu), osądzanie kogoś, rozprawa sądowa, proces' i dalej 'ci, którzy osądzają kogoś, rozstrzygają np. spory, sędziowie, sąd'. Z powodu tych ostatnich znaczeń, które musiały powstać już w epoce wspólnoty prasłowiańskiej, psł. * $s q d ъ$ wszedł też w skład słowiańskiego słownictwa prawnego, por. np. pol. od XIV w. sqad 'organ wymiaru sprawiedliwości', 'rozprawa sądowa, proces', czes. soud 'sąd; proces', ros. sud 'sąd', scs. sqdb 'rozprawa sądowa, proces; wyrok; sprawiedliwość; sąd, trybunał; sądzenie'.

*duma 'myśl, zamysł, mniemanie, rozmyślanie': pol. duma w przest. znaczeniu 'myśl, rozmyślanie, marzenie', w XVI w. też 'błędne mniemanie, wymysł, urojenie' (ale podstawowe znaczenia w języku polskim są inne: 'poczucie godności', 'to, co jest przedmiotem dumy, chluba, chwała; zaszczyt', 'zarozumiałość, pycha', o nich niżej) (z polskiego zapożyczone czes. poet. duma 'myślenie, rozmyślanie, marzenie', słowac. duma 'ts.'), poza tym wyraz występuje w językach wschodniosłowiańskich i południowosłowiańskich: strus. duma 'myśl; zamysł, zamiar; rozum', a także 'rada, narada, obrady; wskazówka', ros. dúma 'myśl, dumanie' (też 'rosyjski parlament', hist. 'rada bojarów'), ukr. dúma 'myśl, myślenie', brus. dúma 'myśl, rozum', dial. dumá też 'myślenie, myśl', bułg. dúma 'słowo, wyraz', ludowe 'rozmowa', 'złe słowa', 'myśl', maced. dial. duma 'słowo, wyraz; myśl', serb. dial. düma 'skryta, tajna myśl', 'mówienie, mowa', 'rozum, pamięć'. Psł. *duma jest wyrazem trudnym do objaśnienia, nie ma pewnej etymologii (szczegółowo o dotychczasowych wersjach etymologicznych z danymi bibliograficznymi zob. SP V, 90-91). Uznawanie przez niektórych badaczy rzeczownika *duma za derywat od czasownika *dumati 'rozmyślać, myśleć, zastanawiać się, medytować, sądzić' (o którym niżej) nie rozwiązuje problemu, bowiem objaśnienie genezy czasownika *dumati jako wyrazu podstawowego napotyka na jeszcze 
większe trudności. Często przyjmowano, że psł. *duma zostało zapożyczone z germańskiego, jako ewentualne źródła wyrazu wskazywano goc. dōms $\mathrm{m}$. 'orzeczenie sądowe, zdanie, sąd, osąd' i 'sława', stang. dōm 'mniemanie, wyrok, sąd; rada, zgromadzenie', stnord. dómr 'zgromadzenie sądowe' (wyrazy te wyprowadza się z pragerm. *domaz, które ma kontynuować pie. * $d^{h} \bar{o}-$ mo- 'coś ustanowionego, prawo' utworzone od pie. pierwiastka werbalnego $d^{h} \bar{e}-$ 'kłaść, stawiać'). Wyprowadzanie psł. *duma z germ. *dōma- napotyka jednak na trudności przede wszystkim fonetyczne, bowiem germ. $\bar{o}$ nie było przejmowane przez Słowian ani jako dyftong -ou- (jeśli byłoby to wczesne zapożyczenie), ani jako - u- (gdyby w grę wchodziło zapożyczenie ze schyłku epoki prasłowiańskiej, po monoftongizacji dyftongów). Za zapożyczeniem nie przemawia także różnica rodzaju między słowiańskim rzeczownikiem żeńskim i germańskim męskim. Także podstawowe znaczenie wyrazu słowiańskiego 'myśl, zamysł, mniemanie, rozmyślanie' jest dość różne od znaczeń germańskich 'orzeczenie sądowe, sąd, zgromadzenie sądowe, rada' (najbliższe temu jest znaczenie ruskie 'rada, narada, obrady', które wszakże wywieść można z podstawowego znaczenia słowiańskiego i które ma bliską paralelę w ewolucji znaczeniowej psł. *sQdz). Wreszcie trzeba dodać, że niewątpliwe zapożyczenia $\mathrm{w}$ rozpatrywanym dziale słownictwa pojawiają się znacznie później, dopiero w odrębnych językach słowiańskich. Uzasadnione poważne wątpliwości co do obcego pochodzenia psł. *duma skłaniały etymologów do poszukiwania innych objaśnień genezy wyrazu. Jedna z wersji etymologicznych przyjmuje pochodzenie psł. *duma z prapostaci $* d^{h}$ ou(o) $m \bar{a}$, czyli miałby to być derywat z sufiksem - $m \bar{a}$ od pie. *dheu(a)- 'wiać, dąć; sypać, rozpraszać się, wirować, unosić się kłębami' (derywatem od tego pierwiastka jest psł. *dymb, pol. $d y m$ ), nie jest jednak jasne, jakie miałoby być pierwotne znaczenie pochodnego psł. *duma (czyżby myśli rozumiane jako 'to, co wiruje, unosi się w głowie'?). Inna próba rodzimej etymologii psł. *duma uznaje ten wyraz za derywat z suf. -ma od psł. *duti 'wiać, dać, dmuchać, ale i tu niejasna pozostaje pierwotna, etymologiczna semantyka wyrazu. Nawiasem mówiąc, ta ostatnia wersja etymologiczna byłaby stosowna dla pol. duma 'pycha, zarozumiałość', gdyż miałaby doskonałe paralele semantyczne np. w pol. buta 'hardość, pycha, wyniosłość' (jest to rzeczownik dewerbalny od psł. *butěti 'wzdymać się, puchnąć, nabrzmiewać, pęcznieć'), w pol. pycha 'próżność, wyniosłość, zarozumiałość' (będącym rzeczownikiem dewerbalnym od psł. *pychati 'dyszeć, sapać, dmuchać’), w kasz. buұa 
'pycha, zarozumiałość' (deverbativum od psł. *buchati 'gwałtownie się rozprzestrzeniać, puchnąć, nabrzmiewać'). Jest jednak bardzo prawdopodobne, że pol. duma 'zarozumiałość, pycha, poczucie godności' otrzymało takie znaczenie w wyniku ewolucji na gruncie polskim pierwotnego znaczenia 'rozmyślanie, mniemanie o sobie'.

4. 'myśleć, rozmyślać, rozważać, sądzić, mniemać': *mbněti 'myśleć, sądzić, uważać, mniemać': stpol. mnieć 'mniemać, przypuszczać, sądzić, uważać', stczes. mnieti 'myśleć, przypuszczać, mieć na względzie; uważać za kogoś, za coś', czes. mnit, dawne mněti 'ts.', słowac. mniet' 'myśleć, mniemać, przypuszczać', strus. mbniti / mbněti, mbnju 'myśleć, mniemać, przypuszczać, wyobrażać sobie, mieć na względzie; uważać za kogoś, za coś', ros. mnitb 'mniemać, sądzić, wyobrażać sobie', ukr. dial. mnity /mnýty 'myśleć, mniemać, wiedzieć', stbrus. mneti (mniti) 'myśleć, sądzić, przypuszczać, uważać', scs. mbněti, mbńq 'sądzić, mniemać', bułg. dawne i dial. mnja 'myśleć, sądzić, uważać', serb. dial. mnëti / mnïti, chorw. dawne i dial. mnïti, mnîm 'myśleć, sądzić, mniemać, przypuszczać', słoweń. mnéti, mním 'myśleć'. Psł. *mbněti ma dokładne odpowiedniki w językach bałtyckich (lit. minëti, menù 'wspominać słowem, po imieniu, wymieniać', 'pamiętać, przypominać (sobie, komuś', 'obchodzić, świętować (rocznicę)', łot. minêt, minu 'pamiętać; zgadywać') i jest pokrewne z łac. memin̄, meminisse 'przypominać sobie, pamiętać, wspominać', het. memma- 'mówić'; podstawę wszystkich tych wyrazów stanowił pie. pierwiastek werbalny *men- 'powziąć myśl, pomyśleć' (zob. np. Miklosich 188, Berneker II, 75, Brückner 341-342, Vasmer II, 633, Machek 1968: 370, Schuster-Šewc 936-937, BER IV, 191, ESSJa 21, 113-115, Derksen 2008: 340, Pokorny 726-728, Smoczyński 2007: 401).

*měniti 'myśleć, mniemać, sądzić': pol. od XV w. mienić 'nadawać miano, nazywać; uważać, mieć za kogoś, coś', stpol. też 'myśleć o czymś, mieć coś na myśli, mniemać, sądzić, twierdzić, utrzymywać; chcieć czegoś; uważać, wyznawać; nadmieniać, wspominać; wymieniać', dawne 'mówić, wypowiadać', dial. 'nazywać', dłuż. mjěniś / měniś 'myśleć', głuż. měnić 'mniemać, sądzić, myśleć, uważać; przypuszczać, domyślać się, spodziewać się; mieć na myśli, na uwadze', stczes. mieniti 'zwracać swoje myśli; zamierzać', mieniti si 'objaśniać, rozmawiać, znaczyć', czes. mínit 'sądzić, uważać, mniemać; mieć na myśli, rozumieć; zamierzać', słowac. mienit' 'ts.', strus. měniti 'myśleć o czymś, mieć na myśli, rozumieć; uważać za kogoś, za coś; nazywać, 
wymieniać; wspominać, ukr. dial. m’inýty 'obiecać', scs. měniti 'myśleć, sądzić, mniemać; wierzyć; wspominać; uważać za kogoś, za coś; zamyślać, zamierzać', serb. dial. méniti, chorw. dial. mijèniti 'myśleć, rozmyślać, wahać się', słoweń. méniti 'myśleć, mniemać, sądzić'. Psł. *měniti jest najprawdopodobniej pokrewne z wyrazami germańskimi i celtyckimi: stwniem. meina 'myśl, zdanie, mniemanie, zamierzenie', meinen 'myśleć, mniemać, mówić' (> niem. meinen 'mniemać, myśleć, sądzić, wierzyć, przypuszczać; mieć na myśli, rozumieć, mówić; mieć zamiar'), stang. mān 'pogląd, opinia; wspomnienie', mœnan 'myśleć, mniemać, mówić; narzekać', stirl. mian 'pragnienie'; wyrazy te sprowadza się do pie. *mei-no- 'mniemanie, pogląd, zamiar' (zob. np. Miklosich 188, Berneker II, 49, Trautmann 165, Brückner 341-342, Vasmer II, 633, ESSJa 18, 174-175, Snoj 1997: 334, Boryś 2005: 324, Pokorny 714). Bliskość postaci i semantyki psł. *měniti i *mbněti skłaniała część badaczy (por. np. Skok II, 445, Bezlaj II, 177) do uznania pokrewieństwa obu czasowników mimo trudności w objaśnieniu rzekomej alternacji rdzennych samogłosek $*_{b}: * \check{e}$, np. całkiem nieprawdopodobna jest próba wyjaśnienia genezy *-ě- przez V. Machka (Machek 1968: 363), nie przekonuje również doszukiwanie się w *měniti czasownika kauzatywnego od *mbněti (Bańkowski 2000: II, 177). R. Derksen (2008: 312) sugeruje identyczność *měniti 'myśleć' z psł. *měniti ‘dokonywać zmiany, wymiany, zamiany’ i dopuszcza pierwotne znaczenie 'cosequentively present one's meaning'.

*mysliti 'myśleć, rozmyślać’: pol. myśleć, dawniej od XIV w. i dziś dial. myślić, myśle 'rozumować', 'pamiętać o kimś, o czymś, dbać, troszczyć się', 'nosić się z zamiarem, zamierzać, chcieć coś zrobić' (pol. bezokolicznik myśleć wtórny, przez analogię do typu widzieć), dłuż. mysliś 'myśleć; uważać, sądzić', głuż. myslić 'myśleć; zamierzać', czes. myslet / myslit 'myśleć', słowac. mysliet' 'ts.', strus. od XI w. mysliti 'myśleć, rozmyślać; zamierzać', ros. mýslitb 'myśleć, sądzić', ukr. mýslyty 'myśleć; obmyślać; troszczyć się; wyobrażać sobie', brus. mýslicb 'myśleć, rozmyślać; pragnąć, scs. mysliti 'myśleć, rozmyślać, zastanawiać się, rozważać; zamierzać', bułg. míslja 'myśleć; zamyślać, zamierzać', maced. misli 'myśleć, rozmyślać; uważać, cenić, wierzyć; zamierzać, chcieć; starać się', chorw. i serb. mïsliti 'myśleć; sądzić, mniemać; uważać, być przekonanym; mieć zamiar', słoweń. mislíti 'myśleć, mieć na myśli', mislíti si 'wyobrażać sobie'. Psł. *mysliti to czasownik odrzeczownikowy, od psł. *myslb 'myślenie, myśl'. W językach słow. ten czasownik ma liczną rodzinę czasowników prefigowanych, z których co naj- 
mniej część powstała zapewne już w epoce wspólnoty prasłowiańskiej, np. *domysliti sę (pol. domyślić się), *namysliti sę (pol. domyślić się), *pomysliti (pol. pomyśleć), *permysliti (pol. przemyśleć), *orzmysliti (pol. rozmyślić się), *umysliti (pol. umyślić), *vymysliti (pol. wymyślić). Od takich przedrostkowych czasowników powstawały dewerbalne rzeczowniki należące do omawianego działu leksyki, najczęściej jednak ograniczone do części języków słowiańskich lub mające w różnych językach nieco inne znaczenia, np. pol. od XIV w. umyst 'zespół myślowych, poznawczych funkcji mózgu, zdolność myślenia, pojmowania, rozumowania, rozum, intelekt', dawniej od XV w. i dziś dial. 'zamiar, zamysł, postanowienie', w stpol. także 'znaczenie, sens', 'troska', 'zaufanie, ufność, nadzieja', w gwarach również 'myśl, pomyślenie' i 'rozwaga', odpowiednikami są np. słowac. úmysel 'zamiar', czes. úmysl 'zamiar, zamierzenie, intencja', ros. úmysel 'zamiar, intencja, cel', wszystkie rodzaju męskiego, ale chorw. i serb. ümisao, -sli 'pomysł; zamiar, zamysł; premedytacja; urojenie’. Takie różnice przemawiają przeciw możliwości rekonstrukcji psł. *umyslъ (mimo istniejących zbieżności formalnych i częściowo identycznej semantyki), raczej mamy tu derywaty powstałe na gruncie poszczególnych języków słowiańskich. Podobnie ma się rzecz z innymi pokrewnymi wyrazami, jak np. pol. namyst, pomyst, zamyst.

*dumati 'rozmyślać, myśleć, zastanawiać się, medytować, sądzić': pol. od $\mathrm{XV}$ w. dumać 'rozmyślać, zastanawiać się, medy tować', poza tym w językach wschodniosłowiańskich i południowosłowiańskich: strus. od X w. dumati 'radzić, odbywać naradę, udzielać rad', 'myśleć, mniemać, sądzić', 'obmyślać, zamierzać, planować, ros. dúmatb 'myśleć, rozmyślać; sądzić, mniemać; frasować się, trapić się, ukr. dúmaty 'myśleć, rozmyślać', brus. dúmacb 'myśleć, rozmyślać; przypuszać, sądzić, mniemać', cs. dumati, dumajo 'putare; consulere', bułg. ludowe i dial. dúmam 'mówić; rozmawiać; myśleć, rozmyślać, mniemać; radzić', maced. dial. duma 'myśleć; pamiętać; mówić', duma se 'rozmyślać', chorw. i serb. dial. dúmati, dûmām 'rozmyślać, głęboko myśleć; intensywnie coś przeżywać; mówić, rozmawiać; radzić, doradzać', słoweń. dial. dumati 'myśleć'). Psł. *dumati to czasownik denominalny od psł. *duma ‘myśl, zamysł, mniemanie, rozmyślanie' (zob. SP V, 91-92, Boryś 2005: 132); odwrotny kierunek derywacji w ESSJa 5, 154-156.

*sqditi 'wyrażać zdanie, oceniać, osądzać' (por. pol. XIV sądzić, stpol. sędzić 'oceniać, osądzać', 'być zdania, uważać, mniemać', przest. 'przyznawać, przeznaczać coś dla kogoś’, głuż. sudźić 'osądzać, oceniać; wnioskować 
(z czegoś)', czes. soudit 'osądzać, oceniać; mniemać, uważać; przeznaczać coś dla kogoś', ros. sudit' 'sądzić, mniemać', scs. sqditi 'dochodzić do wniosku'). Psł. *sqditi to czasownik odrzeczownikowy od psł. *sqdz 'zdanie, opinia, pogląd' (ponieważ podstawowy rzeczownik miał też znaczenie 'rozprawa sądowa, sąd', pochodny czasownik znaczył też 'sprawować sąd, wydawać wyrok'), zob. np. Boryś 2005: 539.

5. 'wiedzieć, znać': *znati, *znajo 'znać, wiedzieć': pol. od XIV w. znać, znam 'mieć pewien zasób wiadomości o kimś, o czymś; umieć coś; widać', dłuż. znaś, znaju / znajom 'znać; przyznawać, potwierdzać; świadczyć przed sądem', głuż. znać, znaju 'znać', czes. znát, znám 'znać; umieć; widać', słowac. znat', znám 'poznać, znać', ros. znatb, znáju 'znać, wiedzieć, umieć coś, rozumieć', ukr. znáty, znáju 'znać, wiedzieć', brus. znacb, znáju 'ts.', scs. znati, znajo 'znać, wiedzieć', bułg. znája 'wiedzieć; umieć; znać', maced. znae 'znać, wiedzieć; umieć, potrafić; rozumieć', chorw. i serb. znäti, znâm 'znać, wiedzieć; umieć, potrafić; być poinformowanym; mieć zwyczaj’, słoweń. znáti, znâm 'umieć; znać'). Psł. *znati pokrewne jest z lit. žinóti 'znać, wiedzieć' (zaprzeczone nežnóti 'nie znać, nie wiedzieć'), łot. zinât 'znać, wiedzieć', stind. janấti 'wie, zna', gr. gignốskō 'znam', łac. nōscō, nōscere 'poznać, dowiedzieć się’, wszystkie od pie. *géen- / *ǵno- 'wiedzieć, znać’, por. np. Miklosich 401, Trautman 371, Vasmer II, 100-101, Skok III, 658-659, BER I, 650, Bezlaj IV, 419-420, ESBM III, 339, Boryś 2005: 742-743, Derksen 2008: 546, Fraenkel II, 1311, Smoczyński 2007: 786-787, Pokorny 376.

*věděti, *vědě / *věmb 'być świadomym czegoś, zdawać sobie sprawę z czegoś, orientować się w czymś, wiedzieć': pol. od XIV wiedzieć, wiem w tym samym znaczeniu, dawniej też 'znać', stpol. w XV w. również 'potrafić, umieć, móc', dłuż. wěźeś, wěm 'wiedzieć', głuż. wědźeć, wěm 'ts.', czes. vědět, vím 'ts.', słowac. vediet', vie 'ts.', umieć, potrafić', z negacją 'nie móc', strus. věděti, vědě / věmb 'wiedzieć', ros. védatb 'wiedzieć; zawiadywać, zarządzać', ukr. vídaty, -aju 'zawiadywać, zarządzać' przest. 'wiedzieć, znać', brus. védacb 'znać, wiedzieć; umieć; rozumieć; zawiadować, kierować', scs. věděti, vědě/ věmb 'wiedzieć, znać', chorw. dial. kajk. vëdeti, viem 'znać, być zdolnym', słoweń. védeti, vém 'wiedzieć'). Psł. *véděti to archaiczny czasownik atematyczny, pokrewny ze stpr. waist 'wiedzieć', goc. wait 'wiem' (dziś niem. ich weiss 'ts.'), łac. vīdī 'widziałem', gr. oída 'wiem', stind. véda 'wiem'. Psł. *vědéti to osobliwy czasownik, wyróżniający się dwiema forma- 
mi 1. osoby sg. praes.: obok regularnej w czasownikach atematycznych formy *věmb $(<*$ *ěd-mb < *uoìd-mı̌) poświadczona jest niezwykła, wyjątkowa forma *vědě ‘wiem' (scs., strus., stczes. vědě 'wiem'), kontynuująca pie. formę 1. osoby sg. perfectum medium *uoidai 'widziałem' (od pie. *ueid'widzieć'). Właśnie ta prastara forma *vědě, a raczej jej wcześniejsza postać *uoiddai 'widziałem', stanowiła podstawę psł. *věděti (por. np. Miklosich 390, Trautmann 338, Vasmer I, 283, Bezlaj IV, 288, Boryś 2005: 692, Derksen 2008: 518, Pokorny 1125 n.). Rozwój znaczenia przebiegał zapewne w ten sposób: z pierwotnego 'widziałem, zobaczyłem coś, kogoś' powstało nowsze znaczenie 'wiem o czymś, o kimś'.

6. 'umieć': *umĕti 'poznawać, pojmować, rozumieć coś, być biegłym w czymś, umieć, potrafić' (por. pol. od XIV w. umieć 'mieć praktyczną znajomość czegoś, być biegłym w czymś', 'być w stanie coś zrobić, potrafić, w stpol. od XV w. też 'mniemać, myśleć, sądzić, wiedzieć, znać', dłuż. humeś / huměśs 'umieć, znać; rozumieć, pojmować', głuż. dial. wumjeć 'umieć', czes. umět 'umieć', ros. umétb 'umieć, potrafić', ukr. umity 'umieć, potrafić, brus. umécb 'ts.', scs. uměti, umějo 'rozumieć, pojmować coś', bułg. uméja 'umieć', maced. umee 'umieć, potrafić', chorw. ùmjeti, serb. ùmeti 'umieć, potrafić, móc', słoweń. uméti, úmem 'umieć'). Psł. *uměti to czasownik odrzeczownikowy od psł. *umъ 'rozum' (zob. np. Vasmer IV, 161-162, Bezlaj IV, 263, Boryś 2005: 666-667).

7. 'rozumieć, pojmować’: *orzumĕti 'pojąć, poznać, zrozumieć coś’: pol. od XIV w. rozumieć 'pojmować coś', dawne w XVI w. też 'uważać za coś', dłuż. rozmeś / rozměś (dawne rozumeśs) 'rozumieć, pojmować', głuż. rozumić, dial. rozumjeć 'ts.', czes. rozumět 'rozumieć; znać się na czymś', słowac. rozumiet' 'ts.', ukr. rozumity 'rozumieć, pojmować', scs. razuméti 'rozumieć, zrozumieć, pojmować, pojąć; być mądrym, zmądrzeć', 'poznać, poznawać; dowiedzieć się, dowiadywać się; zwracać uwagę, bułg. ludowe razuméja 'zrozumieć', maced. dial. razumi 'zrozumieć, pojąć', chorw. razùmjeti, serb. razùmeti '(z)rozumieć, pojąć, pojmować, zda(wa)ć sobie sprawę', słoweń. razuméti, razúmem '(z)rozumieć, pojąć, pojmować'. Psł. *orzuméti to derywat z przedrostkiem *orz- od psł. *uměti 'poznawać, pojmować, rozumieć coś, być biegłym w czymś, umieć, potrafić'. Jest możliwe, że w poszczególnych językach słowiańskich na starszy czasownik przedrostkowy nawarstwił się 
późniejszy czasownik odrzeczownikowy od psł. *orzums 'rozum', to by tłumaczyło dwuaspektowość czasownika w językach południowosłowiańskich, np. scs. razuméti.

8. 'pamiętać, zachowywać w pamięci, przypominać sobie, wspominać': *pombněti 'wspominać, przypominać sobie, pamiętać': pol. od XIV w. pomnieć 'mieć, zachowywać w pamięci, nie zapominać, pamiętać', 'zważać na coś, mieć coś na względzie', w stpol. też wyjątkowo 'zapomnieć', dawniej także 'wspominać, przypominać sobie', dłuż. pomneś 'pamiętać', głuż. pomnić 'pamiętać, wspominać, czes. pomněti / pomniti 'przypomnieć sobie, wspomnieć', słowac. pomnút', pomne 'przypomnieć sobie', strus. pombniti 'myśleć, pamiętać', ros. pómnitb 'pamiętać, zachowywać w pamięci', ukr. dial. póvnyty 'pamiętać', brus. pómnicb 'ts.', scs. pombnèti 'pamiętać, przypomnieć sobie', bułg. pomnjá 'pamiętać', maced. pomni 'ts.', chorw. i serb. pómniti 'ts.', uważnie słuchać, słoweń. pómneti 'pamiętać. Psł. *po-mbněti to derywat z prefiksem *po- od psł. *mbněti 'myśleć, sądzić, uważać, mniemać'.

*pomęnqti 'wspomnieć', genetycznie czasownik perfektywny z suf. - nQ-, na który wskazuje ros. pomjanútb, pomjanú 'wspomnieć, napomknąć', 'pomodlić się w intencji kogoś', 'pomodlić się (odprawić nabożeństwo) o spokój duszy kogoś, 'urządzić stypę,'wziąć udział w nabożeństwie żałobnym za kogoś', ukr. pom' janúty, -nú 'wspomnieć', u Hrinčenki też pomenýty 'ts.', brus. pamjanúcb cerk. = ros. pomjanútb, dial. (Nosovič) pomjanúcbca 'upomnieć się, często przypominając', scs. pomęnoti, pomęno 'wspomnieć, przypomnieć sobie' i poměnoti 'ts.', bułg. pomená, -ěš 'modląc się, uczcić pamięć zmarłego', maced. pomene 'wspomnieć' (por. też pochodne nomen deverbale: serb. pömēn, maced. pomen 'wypominki za zmarłych na cmentarzu i w cerkwi; wspomnienie'), chorw. i serb. (od XIV w.) poménuti, pòmēnēm 'wspomnieć, pamiętać'; w poszczególnych językach słowiańskich poświadczone są postaci z dalszymi prefiksami *vbz-, ${ }^{*} s b-$ stczes. vzpomanúti 'wspomnieć, przypomnieć sobie, pamiętać, czes. vzpomenouti, -nu 'ts.', rus.-cs. vъspomęnuti, vъspomęnu 'wspomnieć, przypomnieć sobie', ros. vspomjanútb, -mjanú 'wspomnieć', ukr. spom'janúty, -nú 'ts.', brus. uspomjanúcb 'ts.', dial. spomjanúcb 'wspomnieć, przypomnieć sobie', scs. vъspomęnoti 'ts.', vъspoměnoti, bułg. spomená 'wspomnieć', u Gerova też o wspomnieniu zmarłego, maced. spomene 'wspomnieć', chorw. i serb. spoménuti, spòmēnēm 'wspomnieć'. W psł. *pomęnoti, związanym zapewne z *pombněti, niejasne 
jest rdzenne -e-. Machek 1968: 370 przyjmował przekształcenie pierwotnych postaci *pomęti, *pomeno, pokrewnych z lit. at-minti, àt-menu 'przypomnieć' (zob. też ESJS 11, 681).

Dyskusyjna jest rekonstrukcja psł. *menqti 'wspominać, pamiętać' (Trautmann 180, Pokorny 726 nn., Machek 1968: 370, a ostatnio szczegółowo Sławski 2000). Według F. Sławskiego czasownik ten poświadczony jest tylko w postaci prefigowanej *po-menoti (też z dalszymi prefiksami *vbz-, ${ }^{*} s$ ) we wszystkich trzech grupach języków słowiańskich, jednakże najbardziej prawdopodobna jest przynależność doń stpol. XIV-XVI w. wspomionqć, wspomione 'wspomnieć, pomyśleć o czymś minionym' (por. też Bezlaj III, 85) i, może, słowac. spomenút', -nie 'wspomnieć', spomenút' si 'przypomnieć sobie' oraz ukr. dial. (u Hrinčenki) pomenýty 'wspomnieć' (jeśli nie mamy $\mathrm{w}$ nich do czynienia z wtórnymi -e-). Sławski zalicza do tego czasownika również przytoczone wyżej chorw. i serb. (od XIV w.) poménuti, bułg. pomená, maced. pomene, których -e- mogłoby kontynuować psł. rdzenne *-e-, ale raczej należy w nich widzieć kontynuanty pierwotnego *po-męnqti poświadczonego w scs. po-męnoti i kontynuujących taką samą prapostać z rdzennym *e- form wschodniosłowiańskich (np. ros. pomjanútb); w artykule Sławskiego wszystkie te postaci zaliczono do *menqti, -ę- zaś w różnych językach słowiańskich objaśniono wtórną nazalizacją - $e-\mathrm{w}$ sąsiedztwie spółgłosek nosowych. Zdaniem Sławskiego psł. *menoti, *meno to prymarny czasownik utworzony od indoeuropejskiego pierwiastka *men- 'powziąć myśl, pomyśleć', mający dokładne odpowiedniki w lit. menù, miñti 'pamiętać, zapamiętywać, przypominać sobie, mieć w pamięci; zgadywać, odgadywać zagadki; nadać imię' (por. Smoczyński 2007: 403-404), por. też stind. mánati 'wspomina'. Pierwotna jest postać praesens (1. sg. *menQ $<$ bsł. *menō, zob. Trautmann 180), natomiast psł. infinitiw ma mieć wtórne *-nQ- przeniesione zdaniem Sławskiego z praesens (pisze, że oczekiwana byłaby postać infinitiwu *męti); wszakże w praes. *meno nie ma sufiksu *-nQ- (-n- należy do rdzenia, a *-Q jest końcówką 1. sg. praes.), jeśli *-nQ- jest w *menoti rzeczywiście sekundarne, to raczej trzeba by przyjać analogię do czasowników typu *mbnQti.

$\mathrm{Na}$ gruncie poszczególnych języków powstawały czasowniki utworzone od psł. *pamętb bądź od jego kontynuantów, np. pol. pamiętać 'mieć w pamięci, nie zapominać, przypominać sobie', słowac. pamätat' 'pamiętać', maced. pameti i pamti 'pamiętać, przypominać sobie', chorw. i serb. pâmtiti 'ts.', czes. pamatovat 'pamiętać'. 
9. 'zapomnieć': *zabyti, *zabode 'zapomnieć': pol. dawne XVIII w. zabyć, zabędę 'zapomnieć', stpol. XV w. 'pozbyć się czegoś', dawne XVI-XVII w. zabywać 'zapominać; pozbywać się', połab. zobål-sa 'zapomniał (się)', głuż. zabyć, zabudu 'zapomnieć', dłuż. zabyś, zabydnu 'ts.', czes. zabýt 'ts.', stczes. zabyti sě 'zapomnieć się; rozzłościć się, wściec się', słowac. zabyt' 'zapomnieć', strus. od XI w. zabyti 'ts.', ros. zabýtb, zabúdu 'ts.', zabýtbsja 'zapaść w półsen; zapomnieć się; ulec zapomnieniu, pójść w zapomnienie', ukr. zabúty, zabúdu 'zapomnieć', brus. zabýcb 'ts.', scs. zabyti, zabodo 'ts.', chorw. dial. zàbiti, zàbudèm 'ts.', czak. zābïti, zābîn i pozābït, pozābîn 'zapomnieć, wypuścić z pamięci', kajk. zãbiti, zãbim i pozãbiti 'ts.', słoweń. przest. i dial. zábiti, -bim 'zapomnieć'. Psł. zabyti to derywat od psł. *byti 'być' (np. Brückner 52, Vasmer II, 71, ESBM III, 279, ESUM II, 215, Bezlaj IV, 375, Polański 1074), jednak niepewne jest pierwotne znaczenie prefigowanego czasownika i jego ewolucja semantyczna. Najbardziej prawdopodobne wydaje się objaśnienie A. S. Mel'ničuka przedstawione w artykule (Мельничук 1967: 63) i ukraińskim słowniku etymologicznym (ESUM II, 215): wychodzi on przypuszczalnie od najwcześniejszego znaczenia czasownika zwrotnego *zabyti sę 'zasiedzieć się, zbyt długo gdzieś przebywać, zabawić' > 'przebywać gdzieś w jednej sprawie lub bezczynnie, nie robiąc czegoś innego ważnego' > 'przestać pamiętać, zapomnieć o jakiejś ważnej sprawie czy obowiązku', z czego nowe znaczenie 'zapomnieć się, nie pamiętać o czymś', w końcu, na wzór innych czasowników, do zwrotnego *zabyti sę został dotworzony niezwrotny czasownik *zabyti ze znaczeniem 'nie pamiętać, zapomnieć (o czymkolwiek)'. Wątpliwe są inne próby objaśnienia semantyki *zabyti, np. przyjmowanie pierwotnego znaczenia 'być za czymś' (Sadnik, Aitzetmüller I, 90), sugestia, że zachowane tu było pierwotne znaczenie psł. *byti 'rosnać' (poświadczone w pokrewnych wyrazach indoeuropejskich i w prasłowiańskim derywacie *bylb 'roślina') z powołaniem na brus. frazę byllëm paraslo 'uległo zapomnieniu, zostało zapomniane' (ESBM III, 279). Zdaniem M. Furlan (w: Bezlaj IV, 375) prefiks $*_{z a-}$ wnosił do derywatu znaczenie 'nie, bez, słabo itp.', prefigowany czasownik *zabyti miałby pierwotnie znaczyć 'nie być, słabo być itp.', z czego miało się rozwinąć 'zapomnieć'. Nie przekonuje odrębna etymologia rozpatrywanego wyrazu przedstawiona przez V. Machka, łączącego psł. *zabyti z rodziną psł. *bbděti 'nie spać, czuwać; czuwać nad czymś, troszczyć się o coś, *buditi 'powodować, że ktoś przestaje spać, budzić; powodować pojawienie się czegoś, wywoływać czuj- 
ność, stany uczuciowe, ich przejawy' i w związku z tym przyjmującego jako pierwotne znaczenie omawianego czasownika prefigowanego 'wyjść ze stanu duchowej świeżości’ (Machek 1968: 708).

Jak i w innych działach leksyki prasłowiańskiej, w słownictwie ujawniły się leksykalne podstawy praindoeuropejskie oraz różne warstwy chronologiczne prasłowiańskich innowacji leksykalnych. W omawianym dziale słownictwa prawie nie ma gotowych wyrazów odziedziczonych z epoki wspólnoty indoeuropejskiej. Za odziedziczony można by uznać psł. rzeczownik **mętb (< pie. *mentis), nie zachował się on wszakże jako samodzielny wyraz, lecz tylko w psł. złożeniu *pa-mętb. Jest mało prawdopodobne, by odziedziczonym z praindoeuropejskiego był psł. rzeczownik * $*_{s} d t$, bliski co prawda pokrewnym wyrazom w innych językach indoeuropejskich, które jednak mają inne postaci morfologiczne.

Za wczesne innowacje epoki prasłowiańskiej można uznać wyrazy oparte na praindoeuropejskich pierwiastkach, nie mające jednak dokładnych odpowiedników indoeuropejskich: psł. *měniti, *myslb, *pamętb, *sods, *umb, *věděti. Zwracają uwagę bałtyckie odpowiedniki psł. czasowników *mbněti i *nati, co zdaje się sugerować, że są to wspólne innowacje bałtosłowiańskie.

Liczniejsze są późniejsze innowacje prasłowiańskie, derywaty utworzone od prasłowiańskich podstaw: dewerbalny rzeczownik *orzumъ, denominalne czasowniki *dumati, *mysliti, *soditi, *uměti i czasowniki prefigowane *pombněti, *pomęnqti, *zabyti.

Prawie cały rozpatrywany dział leksyki prasłowiańskiej jest pochodzenia rodzimego. Być może jedynym zapożyczeniem jest psł. *duma, gdyż mimo trudności fonetycznych germańskie źródło wyrazu wydaje się bardziej prawdopodobne od proponowanych etymologii słowiańskich.

\section{Bibliografia}

BAŃKowski A., 2000, Etymologiczny słownik języka polskiego, t. 1-2, Warszawa: Wydawnictwo Naukowe PWN.

BER = Български етимологичен речник, 1962-2011, т. 1-7, София: Издателство на Българската Академия на Науките.

Berneker E., 1908-1913, Slavisches etymologisches Wörterbuch, Bd. 1-2, Heidelberg: Carl Winter's Universitätsbuchhandlung. 
Bezlaj F., 1977-2005, Etimološki slovar slovenskega jezika, t. 1-4, Ljubljana: Mladinska knjiga.

Boryś W., 1975, Prefiksacja imienna w językach słowiańskich, Wrocław-Warszawa-Kraków-Gdańsk: Wydawnictwo Ossolineum.

Boryś W., 2005, Słownik etymologiczny języka polskiego, Kraków: Wydawnictwo Literackie.

BRÜCKNER A., 1927, Słownik etymologiczny języka polskiego, Kraków: Krakowska Spółka Wydawnicza.

Derksen R., 2008, Etymological Dictionary of the Slavic Inherited Lexicon, Leiden: Brill.

ESBM = Этылмалагічны слоўнік беларускай мовы, 1978-2010, т. 1-13, Мінск: „Навука і тэхніка”.

ESJS = Etymologický slovník jazyka staroslověnského, 1989-2010, hl. red. E. Havlová [z. 7-12: red. A. Erhart, od z. 13: red. I. Janyšková], z. 1-15, Praha: Academia.

ESSJa = Этимологический словарь славянских языков. Праславянский лексический фонд, 1974-2010, отв. редактор О. Н. Трубачев [od t. 32 А. Ф. Журавлев], вып. 1-36, Москва: Издательство „Наука”.

ESUM = Етимологічний словник украӥнської мови, 1982-2008, т. 1-6, Київ: Наукова думка.

FrAENKEL E., 1955-1965, Litauisches etymologisches Wörterbuch, Bd. 1-2, Heidelberg-Göttingen: Winter, Vandenhoeck \& Ruprecht.

Macheк, V., 1968, Etymologický slovnik jazyka českého, Druhé, opravené a doplněné vydání, Praha: Academia.

Meillet A., 1905, Études sur l'étymologie et le vocabulaire du vieux slave, p. 2, Paris: Librairie Émile Bouillon.

Miklosich F., 1886, Etymologisches Wörterbuch der slavischen Sprachen, Wien: Wilhelm Braumüller.

Moszý́ski K., 1967, Kultura ludowa Słowian, t. 2: Kultura duchowa, cz. 1, wyd. drugie, Warszawa: Książka i Wiedza.

POKORNy J., 1949-1959, Indogermanisches etymologisches Wörterbuch, Bd. 1, Bern: Francke Verlag.

Polański K., 1962-1994, Słownik etymologiczny języka Drzewian połabskich, t. 1-6, Wrocław: Ossolineum - Warszawa: Energeia.

REJZEK J., 2001, Český etymologický slovnik, Voznice: Leda.

SAdnik L., Aitzetmüller R., 1975, Vergleichendes Wörterbuch der slavischen Sprachen, Bd. I: $A-B$, Wiesbaden: Otto Harrassowitz.

SCHUSTER-ŠEWC H., 1978-1996, Historisch-etymologisches Wörterbuch der oberund niedersorbischen Sprache, Bd. 1-5, Bautzen: VEB Domowina-Verlag. 
Sкок P., 1971-1974, Etimologijski rječnik hrvatskog ili srpskog jezika, t. 1-4, Zagreb: Jugoslavenska akademija znanosti i umjetnosti.

SŁAWsKI F., 1974, Zarys słowotwórstwa prasłowiańskiego, w: Słownik prasłowiański, t. I, Wrocław-Warszawa-Kraków-Gdańsk: Ossolineum, s. 43-141.

SŁawski F., 2000, Prasłowiańskie menǫti 'wspominać, pamiętać, mentionem facere, commemorare, meminisse', Јужнословенски филолог LVI/3-4, s. 1033-1034.

Smoczyński W., 2007, Słownik etymologiczny języka litewskiego, Wilno: Uniwersytet Wileński.

SNOJ M., 1997, Slovenski etimološki slovar, Ljubljana: Mladinska knjiga.

SP = Słownik prasłowiański, 1974-2001, opracowany przez Zespół Zakładu Słowianoznawstwa (Instytutu Słowianoznawstwa, Instytutu Slawistyki) PAN, F. Sławski (red.), t. 1-8, Wrocław: Ossolineum.

Trautmann R., 1923, Baltisch-Slavisches Wörterbuch, Göttingen: Bandenhoeck \& Ruprecht.

Vaillant A., 1974, Grammaire comparée des langues slaves, t. 4: La formation des noms, Paris: Éditions Klincksieck.

VASMER = Фасмер М., Этимологический словарь русского языка, перевод с немецкого и дополнения О. Н. Трубачева, т. 1-4, Москва 1964-1973: Издательство „Прогресс”.

МЕльничук А. С., 1967, Об одном из важных видов этимологических исследований, Этимология, Москва: „Наука”, s. 57-66.

Топоров В. Н., 1963, К этимологии слав. myslb, Этимлогия, Москва, s. 5-13.

\section{Die älteste slawische intellektuelle Lexik}

\section{( Zus a m m e n f s s ung)}

Der Beitrag ist der Analyse des urslawischen Wortschatzes zum Ausdruck von höheren Hirnfunktionen oder des Intellektes gewidmet. Er untersucht die Herkunft und die existierenden etymologischen Erklärungen der Substantive mit der Bedeutung 'Verstand, Vernunft, Intellekt' (ursl. *ums, *orzumb), 'Gedächtnis' (ursl. *pamętb), 'Denken, Nachdenken, Sinnen, Gedanke, Urteil' (ursl. *myslb, *sodz, *duma) und Verben mit der Bedeutung 'denken, nachdenken, grübeln, überlegen, meinen’ (ursl. *mbněti, *měniti, *mysliti, *dumati, *soditi), 'wissen, kennen’ (ursl. *znati, *věděti), 'können' (ursl. *umĕti), 'verstehen, begreifen’ (ursl. *orzumĕti), 'erinnern, entsinnen' (ursl. *pombněti, *pomęnqti, *pomenqti), ‘vergessen’ (ursl. *zabyti). Fast alle der analysierten Wörter sind im Urslawischen aufgekommen. Nur das ursl. **mętb (< praie. *mentis), das im compositum *pa-mętb erhalten ist, kann man 
als Erbgut bezeichnen. Zu den Wörtern, die auf indoeuropäische Elemente zurückgehen (für einige gibt es Äquivalente in baltischen Sprachen), gehören die frühen urslawischen Innovationen: *mbněti, *-menqti, *měniti, *myslb, *pamętb, *sqdъ, *umъ, *vědět $i, *_{\text {znati. }}$. Die anderen sind spätere urslawische Derivate. Das einzige Lehnwort ist vielleicht ursl. *duma. 
